IFAS Extension

\title{
Florida Foliage House Plant Care: ZZ Plant ${ }^{1}$
}

\author{
R. J. Henny and J. Chen ${ }^{2}$
}

\section{Introduction}

$\mathrm{ZZ}$ plant is enjoyed for its unique appearance, its ability to grow under low light conditions, and its tolerance to drought. ZZ's naturally glossy leaves are so shiny that the plant appears to have been polished.

$\mathrm{ZZ}$ is stemless (Figure 1). Petioles arise directly from the rhizome. Leaflets along the petiole are arranged alternately. A ZZ variety with variegated leaflets is occasionally available for sale through specialty outlets. ZZ plant is often used as a pseudo-bonsai.

Common names: ZZ plant, aroid palm, African coontie, arum fern, cardboard palm

Scientific name: Zamioculcas zamiifolia Engler and Prantl

Plant family: Araceae (the aroid family)

Origin: Native to eastern Africa, Kenya, South Africa, and Tanzania.

\section{Indoor/Home/Office Cultivation Information}

Light requirement: $\mathrm{ZZ}$ is easily maintained under low light interiors in homes and offices.

Soil preference: Any well-drained peat- or bark-based potting soil can be used.

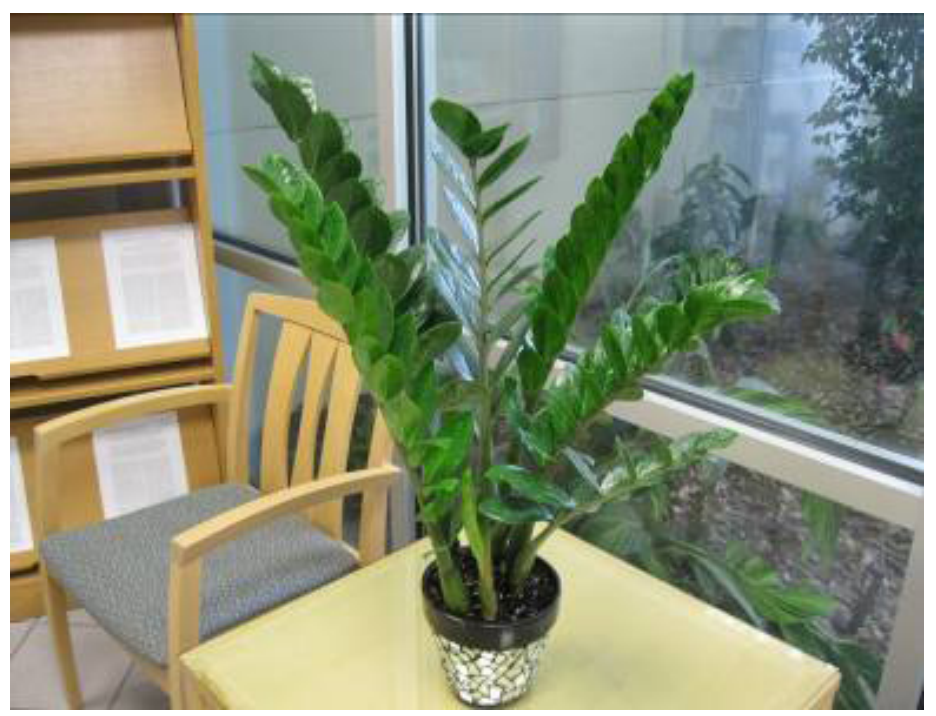

Figure 1. Zamioculcas zamiifolia, commonly called "ZZ plant," performs well indoors.

Credits: R. J. Henny

Water requirement: Do not allow ZZ to sit in water. Allow the soil to become dry between waterings.

Drought tolerance: $\mathrm{ZZ}$ is very drought tolerant, although leaf drop may occur (see Outdoor Cultivation below).

Fertilizer requirements: $\mathrm{ZZ}$ is a slow-growing plant, even under favorable conditions. Apply low-dose liquid fertilizer according to manufacturer instructions twice per year.

Salt tolerance: Slight salt tolerance.

1. This document is ENH1219, one of a series of the Environmental Horticulture Department, UF/IFAS Extension. Original publication date July 2013. Visit the EDIS website at http://edis.ifas.ufl.edu.

2. R.J. Henny and J. Chen, professors, Department of Environmental Horticulture, UF/IFAS Extension, Mid-Florida Research and Education Center, Apopka, FL 32703. 
Flowering: ZZ will not bloom under low light conditions, but it may produce inflorescences under certain outdoor conditions (see Outdoor Cultivation below).

Temperature preference: Warm, tropical $65^{\circ} \mathrm{F}-90^{\circ} \mathrm{F}$.

Chill tolerance: Active growth will be reduced and injury may occur below $50^{\circ} \mathrm{F}$.

Freeze tolerance (below $32^{\circ} \mathrm{F}$ ): No.

Pests: No diseases or pests are an issue for this plant. Root rot may occur if ZZ plants are grown in poorly drained soil with excessive water for an extended period of time. If you experience problems with your ZZ plant, take samples to your local UF/IFAS Extension office for diagnosis and to receive treatment recommendations.

\section{Outdoor Cultivation Information}

Outdoor year-round planting: Okay for USDA Hardiness Zones 10B-12.

Soil preference: ZZ is tolerant of a variety of well-drained soil types.

Light requirement: Strong, filtered light, but no direct sun.

Water requirement: Maintain moisture, but provide adequate drainage.

Drought tolerance: Very drought tolerant. During drought conditions, leaflets and the upper portion of the petiole (i.e., rachis) fall off, leaving the swollen petiole base to tide the plant over until the next irrigation or rain.

Fertilizer requirements: Apply a well-balanced, slow-release pelletized fertilizer according to manufacturer recommendations during the warm growing season. Note that ZZ is a slow-growing plant even under favorable production conditions.

Salt tolerance: Slight salt tolerance. Avoid saline or alkaline conditions.

Flowering: In areas of sufficient light, mature ZZ plants may produce blooms. Flowering occurs on mature plants during spring and early summer. The inflorescence appears just above the soil level and consists of a green spathe enclosing a fleshy spadix.

Temperature preference: Warm, tropical $65^{\circ} \mathrm{F}-90^{\circ} \mathrm{F}$.
Chill tolerance: Active growth will be reduced and discoloration may occur below $50^{\circ} \mathrm{F}$.

Freeze tolerance (below $32^{\circ} \mathrm{F}$ ): No.

Pests: No diseases or pests are problematic on this plant. Root rot may occur if plants are grown in poorly aerated, compacted soil with excessive water for an extended period of time. Take samples to your local UF/IFAS Extension office for diagnosis and to receive treatment recommendations.

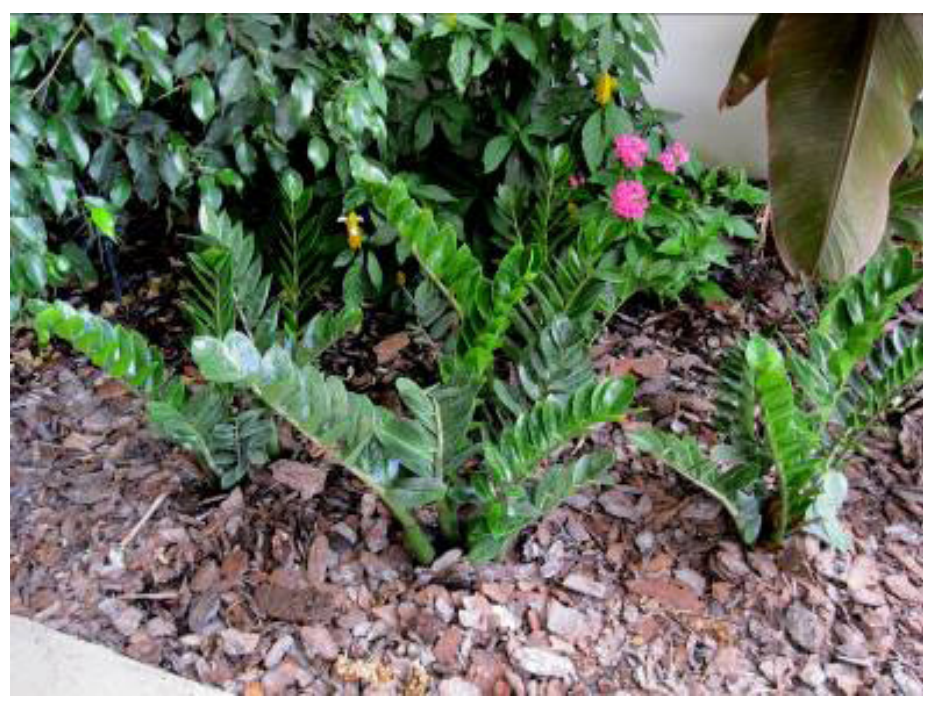

Figure 2. Zamioculcas "ZZ plant" can be used in outdoor landscapes. Credits: R. J. Henny

\section{Additional Resources}

Bown, D. 2000. Aroids: Plants of the Arum Family (2 ${ }^{\text {nd }}$ ed.). Portland, OR: Timber Press. 